\title{
Effects of a new steroidal aromatase inhibitor, TZA-2237, and/or chlormadinone acetate on hormone-induced and spontaneous canine benign prostatic hyperplasia
}

\author{
Kazuto Ito ${ }^{1}$, Yoshitatsu Fukabori ${ }^{1}$, Yasuhiro Shibata ${ }^{1}$, Kazuhiro Suzuki $^{1}$, Mamoru Mieda ${ }^{2}$, Kohtaro Gotanda $^{2}$, \\ Seijiro Honma ${ }^{2}$ and Hidetoshi Yamanaka ${ }^{1}$ \\ ${ }^{1}$ Department of Urology, Gunma University School of Medicine, Maebashi, Japan and ${ }^{2}$ Pharmacological Research Department, Teikoku Hormone \\ Manufacturing Co. Ltd, Kawasaki, Japan \\ (Correspondence should be addressed to K Ito, Department of Urology, Gunma University School of Medicine, Showa-machi 3-39-15, Maebashi, \\ 371-8511, Japan; Email: kzito@med.gunma-u.ac.jp)
}

\begin{abstract}
Objective: It has been known for many years that human benign prostatic hyperplasia (BPH) is composed predominantly of hyperplastic stromal cells rather than epithelial cells. In the present study the effects of a new steroidal aromatase inhibitor on hormone-induced and spontaneous canine BPH were investigated.

Methods: (1) Effects of TZA-2237 on hormone-induced canine BPH. Ten castrated beagles were administered testosterone and androstenedione 6 days/week for 8 months, and divided randomly into three groups after 2 months of treatment as follows. Group I served as controls, Group II was given 0.5 and Group III was given $2.5 \mathrm{mg} / \mathrm{kg} /$ day TZA-2237 5 days/week for 6 months. (2) Effects of TZA2237 on spontaneous canine BPH. Twenty aged beagles with BPH were divided into five groups, Group IV was untreated, Group V was treated with 1 and Group VI with $5 \mathrm{mg} / \mathrm{kg} /$ day TZA-2237 5 days/week for 31 weeks. Group VII was treated with $5 \mathrm{mg} / \mathrm{kg} /$ day Atamestane and Group VIII was treated with $0.3 \mathrm{mg} / \mathrm{kg} /$ day chlormadinone acetate (CMA) 5 days/week. (3) Effects of TZA-2237 combined with CMA on spontaneous canine BPH. Three aged beagles with BPH were treated with $1 \mathrm{mg} / \mathrm{kg} /$ day TZA-2237 and $0.03 \mathrm{mg} / \mathrm{kg} /$ day CMA 5 days/week for 20 weeks (Group IX) and a further three aged beagles with $\mathrm{BPH}$ were treated with $0.3 \mathrm{mg} / \mathrm{kg} /$ day CMA alone 5 days/week (Group X).

Results: Hormone-induced prostatic growth was significantly suppressed in group III compared with that in other groups. In Group III, the intraprostatic aromatase activity, estradiol level and androgen receptor content decreased significantly in comparison with the values in Group I. The prostatic weights in Groups V, VI and VII increased significantly in comparison with the weight in Group IV. Serum LH and testosterone levels in Groups V, VI, and VII increased significantly in comparison with the level in Group IV. The prostatic weight in Group IX was decreased only slightly, but the smooth muscle component was decreased significantly.

Conclusions: TZA-2237 is a new, unique and effective aromatase inhibitor that causes inhibition of both epithelial and stromal compartments in hormone-induced canine BPH. Dual inhibition of androgen and estrogen resulted in inhibition of smooth muscle growth, and should prove effective as a new method of treatment given the atrophic effects on not only the epithelium but also the stroma in human $\mathrm{BPH}$.
\end{abstract}

European Journal of Endocrinology 143 543-554

\section{Introduction}

Benign prostatic hyperplasia (BPH) can be demonstrated histologically in $50 \%$ of 60 -year-old men, and this percentage increases to $90 \%$ in 85 -year-old men (1). Androgens are widely acknowledged to be central to the pathogenesis of $\mathrm{BPH}$. However, $\mathrm{BPH}$ increases in prevalence at the life stage during which plasma androgens are decreasing. The serum and intraprostatic estradiol $\left(\mathrm{E}_{2}\right)$ to testosterone $(\mathrm{T})$ ratio and the level of plasma sex hormone-binding globulin (SHBG) increase with age, and the resulting estrogen-dominant environment has long been suspected to be important for the pathogenesis of BPH (2-5). The evidence for estradiol production in the rat, canine and human prostate was demonstrated using the estrogen formation assay and/ or $\mathrm{H}_{2} \mathrm{O}$ release assay (6). Seppelt demonstrated a significant correlation between the individual physiological estradiol levels and the amount of prostate stroma (7). Suzuki et al. reported that the serum $\mathrm{E}_{2} / \mathrm{T}$ ratio was correlated with the prostatic volume (8) and Shibata et al. demonstrated that the $\mathrm{E}_{2}$ /dihydrotestosterone 
(DHT) ratio in the transitional zone of human $\mathrm{BPH}$ was positively correlated with the prostatic volume, the proportion of stroma (\%) and age (9). Recently, a novel estrogen receptor (ER) cDNA was cloned from the rat prostate, and the putative polypeptide encoded thereby was termed ER- $\beta$ due to its high homology with the classical ER- $\alpha$. Fukabori et al. demonstrated that ER- $\beta$ was localized in human prostatic epithelial cells, which contrasts with the stromal localization of ER- $\alpha$ in the human prostate (10). Recently, Yeh et al. demonstrated the new $\mathrm{E}_{2}$-androgen receptor (AR)-ARA70 pathway in human prostate cancer cells, and concluded that $E_{2}$ may represent an essential ligand of AR that plays an important role in the development and/or functioning of the male reproductive system (11). However, the hypothesis of a non-genomic pathway was proposed in which estrogen, mediated by the SHBG-receptor complex, combines with androgen in setting the pace of prostate growth and function (12). It has been reported that estradiol causes a marked, dose-dependent increase in stromal cytosolic cAMP in the presence of receptorbound SHBG (13). In addition, it appears that the tyrosine kinase pathway mediated by cAMP is capable of activating IGF-I synthesis and paracrine secretion of IGF-I to the epithelial IGF-I receptors, thereby shifting cells from the G1 to the S phase, and causing epithelial proliferation (12).

Thus, estrogen has many roles, and it is of great interest to determine the effect of estrogen deprivation therapy alone and with combined androgen deprivation in prostate physiology and morphology. One aromatase inhibitor, Atamestane, was not an effective treatment for symptomatic $\mathrm{BPH}$ in a prospective randomized double-blind trial (14). However, since that failure resulted in a counter-regulatory increase in androgens, one cannot exclude the possible therapeutic usefulness of estrogen deprivation for $\mathrm{BPH}$.

In this context, we hypothesized that modulation of peripheral estrogen production by inhibitors of aromatization would have a palliative effect on BPH. At first, we investigated the effects and mechanisms of action of a new steroidal aromatase inhibitor TZA-2237 on hormone-induced canine BPH. The inhibitory effects of this compound on prostatic growth were evaluated by transrectal ultrasonography (TRUS) and prostatic weight, and the inhibitory mechanisms of TZA-2237 were also evaluated by endocrinological measurements, including measurement of the levels of estrogen and androgen products, steroid receptor contents and $5 \alpha$ reductase activity. Then, as a pre-clinical study, we also investigated the effect of TZA-2237 with or without CMA on spontaneous canine $\mathrm{BPH}$, and acquired important knowledge that should be useful for the future studies on the clinical applicability of this therapy.

\section{Materials and methods}

\section{Materials}

Testosterone, 4-androstene-3,17-dione (A-dione) and triolein were purchased from Sigma Chemical Co. (St Louis, MO, USA). TZA-2237, 7a-mercapto-D-homo-17oxa-androsta-1,4-diene-3,17a-dione (Fig. 1), Atamestane, 1-methyl-androsta-1,4-diene-3,17-dione and CMA were synthesized at Teikoku Hormone Manufacturing Co. Ltd (Kawasaki, Japan). Radiolabeled $\left[1-\beta-{ }^{3} \mathrm{H}\right] \mathrm{an}-$ drost-4-ene-3,17-dione (specific activity $15 \mathrm{Ci} / \mathrm{mmol}$ ) and $17-\beta-\left[{ }^{3} \mathrm{H}\right]$ estradiol (specific activity $96.5 \mathrm{Ci} / \mathrm{mmol}$ ) for receptor binding assays were purchased from New England Nuclear Research Products (Boston, MA, USA). NADPH was purchased from Kohjin Co. Ltd (Tokyo, Japan).

\section{The characteristics of TZA-2237}

Androgenic activity Three-week-old male rats were castrated under general anesthesia, and 2 weeks later TZA-2237 was administered orally, or testosterone was injected s.c. as a positive control. The animals were killed by prolonged exposure to ether anesthesia $72 \mathrm{~h}$ after a single administration, and the ventral prostate was weighed. Oral treatment with TZA-2237 did not increase the weight of the ventral prostate.

Estrogenic activity TZA-2237 was orally administered, or estradiol was injected s.c. as a positive control for 3 successive days in 3-week-old female rats. On the day following the final administration, each animal was

$7 \alpha$-mercapto-D-homo-17-oxa-androsta-1,4-diene-3,17 $\alpha$-dione

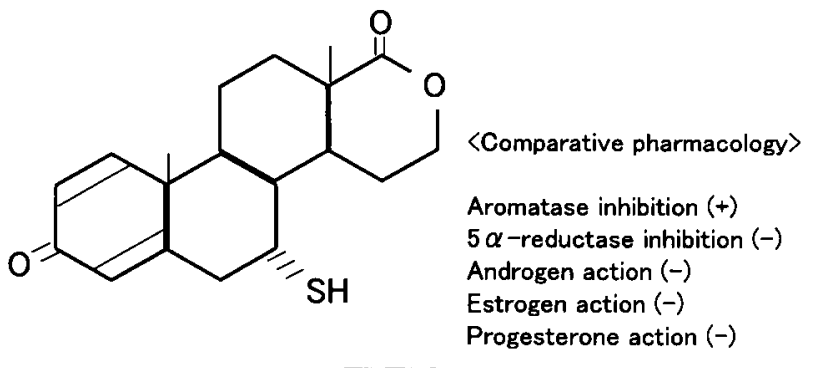

Figure 1 The structure of TZA-2237. 
weighed and killed by prolonged exposure to ether anesthesia, the uterus was excised and weighed. Oral treatment with TZA-2237 did not increase the weight of the uterus.

Progestational activity (Clauberg's test) Immature female rabbits (aged 8-10 days) were primed by s.c. injection of estradiol benzoate at $2 \mu \mathrm{g} / \mathrm{rabbit}$ for 5 successive days. For 5 successive days after that, TZA2237 and reference compounds (norethisterone and medroxyprogesterone acetate) were orally administered. Each animal was weighed on the day following the final administration, and killed by injecting a fatal dose of pentobarbital Na. The uterus was excised and weighed. A uterine horn was fixed in 10\% formalin buffered solution. After fixation, the uterus was sectioned perpendicular to the long axis, and hematoxylin-eosin-stained sections were prepared. Progestational activity was measured by taking the growth of the endometrium as a parameter (the McPhail index) (15). The minimum effective dose was taken to be the minimum dose required to induce endometrial hyperplasia in all animals in the group. TZA-2237 showed no progestational activity in that experiment.

$\mathbf{5} \boldsymbol{\alpha}$-Reductase inhibition activity TZA-2237 showed no inhibitory effects of $5 \alpha$-reductase activity in the in vitro study using the rat ventral prostate tissues.

\section{Canine studies}

A total of 10 young male beagles (2-3 years old) and 20 aged beagles (5-6 years old) were obtained. The animals were kept in a controlled environment (temperature $20^{\circ} \mathrm{C}$, light-dark: $12 \mathrm{~h}$ ). All surgery and examinations were performed under pentobarbital anesthesia. Animals were castrated via the scrotal route 1 week before the start of the studies.

Effects of TZA-2237 on hormone-induced canine BPH On day 0, all animals in the hormone-induced
$\mathrm{BPH}$ groups that were castrated 1 week before were injected i.m. with $30 \mathrm{mg}$ testosterone and $7.5 \mathrm{mg}$ androstenedione in $2 \mathrm{ml}$ triolein 6 times a week for 8 months, and allocated at random into three groups during the last 6 months of androgen treatment as follows. Group I served as a control. Group II was given 0.5 and Group III was given $2.5 \mathrm{mg} / \mathrm{kg}$ of TZA-2237 orally 5 times a week (Table 1 ).

Effects of TZA-2237 on spontaneous canine BPH Twenty aged beagles with $\mathrm{BPH}$ were divided into 5 groups and not treated (Group IV), treated with 1 (Group V) or $5 \mathrm{mg} / \mathrm{kg} /$ day TZA-2237 (Group VI), treated with $5 \mathrm{mg} / \mathrm{kg} /$ day Atamestane (Group VII), or treated with $0.3 \mathrm{mg} / \mathrm{kg} /$ day Chlormadinone acetate (CMA) (Group VIII) (Table 1).

Effects of TZA-2237 combined with CMA on spontaneous canine BPH Six aged beagles with $\mathrm{BPH}$ were divided into two groups, and treated with $1 \mathrm{mg} /$ $\mathrm{kg} /$ day TZA-2237 and $0.03 \mathrm{mg} / \mathrm{kg} /$ day CMA (Group IX), or treated with $0.03 \mathrm{mg} / \mathrm{kg} /$ day CMA alone (Group X).

All dogs were weighed before and after treatment. At the conclusion of the experiment, dogs were killed with an overdose of pentobarbital. The prostate was dissected and weighed, part of it was frozen in liquid nitrogen for biochemical assays and part of it in liquid propane for immunocytochemistry. The remainder of the tissue was fixed with $10 \%$ formaldehyde for histopathological studies. Trunk blood was collected, and the serum fraction was stored at $-70^{\circ} \mathrm{C}$ for estradiol and LH RIA, and testosterone gas chromatography-mass spectrometry (GC-MS).

\section{Prostatic volume measurements}

Before the start of treatment and every 2 months thereafter, the prostatic volume was measured by the method of Berry et al. (16). Transrectal ultrasonography (TRUS) was performed with Toshiba SAL-77B

Table 1 Scheme of treatment.

\begin{tabular}{|c|c|c|}
\hline Group & No. of dogs & Treatment $^{\mathrm{a}}$ \\
\hline I & 4 & Castration: testosterone $(30 \mathrm{mg})$ and androstenedione $(7.5 \mathrm{mg})$ for 8 months \\
\hline II & 3 & $\begin{array}{l}\text { Castration: testosterone }(30 \mathrm{mg}) \text { and androstenedione }(7.5 \mathrm{mg}) \text { for } 2 \mathrm{months} \\
\text { and for a further } 6 \text { months along with aromatase inhibitor TZA-2237 }(0.5 \mathrm{mg} / \mathrm{kg} / \mathrm{day})\end{array}$ \\
\hline III & 3 & $\begin{array}{l}\text { Castration: testosterone }(30 \mathrm{mg}) \text { and androstenedione }(7.5 \mathrm{mg}) \text { for } 2 \text { months } \\
\text { and for a further } 6 \text { months along with TZA-2237 }(2.5 \mathrm{mg} / \mathrm{kg} / \mathrm{day})\end{array}$ \\
\hline IV & 4 & None (untreated control) \\
\hline $\mathrm{V}$ & 4 & TZA-2237 (1 mg/kg/day) for 31 weeks \\
\hline VI & 4 & TZA-2237 (5 mg/kg/day) for 31 weeks \\
\hline VII & 4 & Aromatase inhibitor Atamestane $(5 \mathrm{mg} / \mathrm{kg} /$ day $)$ for 31 weeks \\
\hline VIII & 4 & Antiandrogen CMA $(0.3 \mathrm{mg} / \mathrm{kg} / \mathrm{day})$ for 31 weeks \\
\hline IX & 3 & TZA-2237 $(1 \mathrm{mg} / \mathrm{kg} / \mathrm{day})$ and CMA $(0.03 \mathrm{mg} / \mathrm{kg} / \mathrm{day})$ for 20 weeks \\
\hline $\mathrm{X}$ & 3 & CMA $(0.03 \mathrm{mg} / \mathrm{kg} / \mathrm{day})$ for 20 weeks \\
\hline
\end{tabular}

${ }^{\text {a }}$ Testosterone and androstenedione were given 6 times a week intramuscularly. The other substances were given orally 5 times a week. 
and PVL-516S transducers (Toshiba Medical Co., Tokyo, Japan). The prostate was scanned along the sagittal and transaxial planes. The maximum-sized prostate image was freeze-framed, and the length (in $\mathrm{cm}$ ) and the height of the prostate (in $\mathrm{cm}$ ) were measured in the sagittal plane and the width of the prostate (in $\mathrm{cm}$ ) was measured in the transaxial image. The prostate volume was calculated using the following formula:

Prostate volume $=0.62 \times$ length $\times$ height $\times$ width +1.16 .

\section{Determination of serum LH level}

Serum concentrations of LH were determined by RIA as reported previously by Nett et al. (17), using porcine LH (LER-778) for radioiodination and anti-porcine $\mathrm{LH}$ serum. Purified canine LH (LER-1685) was used as a reference standard.

\section{Determination of serum testosterone}

T- $\mathrm{d}_{3}$ (5ng) was added as an internal standard to each volume of serum $(1 \mathrm{ml})$, and $1 \mathrm{ml} \mathrm{H}_{2} \mathrm{O}$ was added to the serum which was then applied to a Bond Elut C18 cartridge column $(3 \mathrm{ml})$ that had been prewashed with two volumes each of methanol and distilled water. The columns were then washed successively with $3 \mathrm{ml}$ each of $30 \%$ acetonitrile $/ 70 \% \mathrm{H}_{2} \mathrm{O}$. The steroid fraction was eluted with $2.5 \mathrm{ml} 70 \%$ acetonitrile $/ 30 \% \mathrm{H}_{2} \mathrm{O}$ and dried with the centrifugal evaporator. The extract was dissolved in $3 \mathrm{ml}$ benzene and applied to a Bond Elut $\mathrm{CN}$ cartridge column $(3 \mathrm{ml})$ that had been prewashed with $10 \mathrm{ml}$ benzene. The column was washed with $2.5 \mathrm{ml}$ each of benzene and $2 \%$ ethyl acetate $/ 98 \%$ benzene, and then the testosterone fraction was eluted with $3 \mathrm{ml} \mathrm{10 \%} \mathrm{ethyl} \mathrm{acetate} / 90 \%$ benzene. The fraction was dried under nitrogen in a water bath at $45^{\circ} \mathrm{C}$. The testosterone concentrations were quantified by GC-MS.

\section{Determination of testosterone, DHT and estradiol in the prostate}

The frozen tissue (200-500 mg) was pulverized in liquid nitrogen and homogenized in $10 \mathrm{ml}$ of $0.1 \mathrm{M}$ phosphate buffer (pH 7.0) using an Ultra-Turrax homogenizer (Junke and Kunkel) in an ice bath. T$\mathrm{d}_{3}(5 \mathrm{ng}),\left[{ }^{3} \mathrm{H}\right]$ DHT (2000 d.p.m.) or $\left[{ }^{3} \mathrm{H}\right] \mathrm{E}_{2}$ was added as an internal standard to each piece of homogenized tissue, and then $20 \mathrm{ml}$ ethylacetate/n-hexane (3:1) was added to the samples and the mixture was shaken for 10 min. Each organic layer was transferred to a test tube. The organic solvent was washed successively with $5 \% \mathrm{NaHCO}_{3} / 95 \% \mathrm{H}_{2} \mathrm{O}$ and distilled water, and dried over anhydrous $\mathrm{Na}_{2} \mathrm{SO}_{4}$. After evaporation of the organic solvent, the extract was dissolved in $3 \mathrm{ml} 30 \%$ acetonitrile $/ 70 \% \mathrm{H}_{2} \mathrm{O}$ in a warm bath, and then applied to a Bond Elut C18 cartridge column $(3 \mathrm{ml})$ that had been prewashed with two volumes each of methanol and distilled water. The columns were then washed successively with $3 \mathrm{ml}$ each of distilled water and 30\% acetonitrile $/ 70 \% \mathrm{H}_{2} \mathrm{O}$. The steroid fraction was eluted with $2.5 \mathrm{ml} 70 \%$ acetonitrile $/ 30 \% \mathrm{H}_{2} \mathrm{O}$ and dried under nitrogen in a water bath at $45^{\circ} \mathrm{C}$. The extract was dissolved in $1 \mathrm{ml}$ benzene and applied to a Bond Elut $\mathrm{CN}$ cartridge column $(3 \mathrm{ml})$ that had been prewashed with $10 \mathrm{ml}$ benzene. The column was washed with $1 \mathrm{ml}$ benzene and $2 \%$ ethyl acetate $/ 98 \%$ benzene, and then the testosterone fraction was eluted with $3 \mathrm{ml} \mathrm{10 \%} \mathrm{ethyl}$ acetate $/ 90 \%$ benzene, the DHT fraction was eluted with $3.5 \mathrm{ml} 2 \%$ ethyl acetate $/ 98 \%$ benzene, and the estradiol fraction was eluted with $5 \mathrm{ml} \mathrm{10 \%} \mathrm{ethyl} \mathrm{acetate/90 \%}$ benzene. Each fraction was dried under nitrogen in a water bath at $45^{\circ} \mathrm{C}$. The testosterone concentrations were quantified by GC-MS and the DHT and estradiol concentrations were determined by RIA corrected for the recovery of radioactivity.

\section{Assay for aromatase activity in the prostate}

Aromatase activity was measured by an ${ }^{3} \mathrm{H}_{2} \mathrm{O}$-release assay. The frozen tissue was pulverized in liquid nitrogen and homogenized in four volumes of $0.1 \mathrm{M}$ phosphate buffer ( $\mathrm{pH} 7.5)$ with an Ultra-Turrax homogenizer in ice water. The homogenate was centrifuged at $900 \mathrm{~g}$ for $10 \mathrm{~min}$, and the supernatant was used as an enzyme source. The reaction mixture containing $\left[{ }^{3} \mathrm{H}\right]$ androstenedione $(50 \mu \mathrm{Ci})$, NADPH (1 mg), homogenate, and $0.1 \mathrm{M}$ phosphate buffer in a final volume of $1 \mathrm{ml}$ was incubated at $37^{\circ} \mathrm{C}$ for $45 \mathrm{~min}$. The reaction mixture was stopped by chilling on ice, and supplemented with $1 \mathrm{ml}$ $\mathrm{H}_{2} \mathrm{O}$ and $3 \mathrm{ml} \mathrm{CH}_{3} \mathrm{Cl}$. This solution was vortexed and centrifuged at $1500 \mathrm{~g}$ for $10 \mathrm{~min}$. Aliquots of the aqueous phase $(1.0 \mathrm{ml})$ were analyzed for ${ }^{3} \mathrm{H}$ content using a liquid scintillation counter (LSC 3500, Aloca). The aromatase activity was expressed as $\mathrm{fmol} / \mathrm{h} / \mathrm{mg}$ protein. The protein content was determined by the methods of Lowry (18).

\section{Assay for $5 \alpha$-reductase activity in the prostate}

The pulverized dog prostate tissue was homogenized in ten volumes of $0.1 \mathrm{M}$ phosphate buffer with an UltraTurrax homogenizer in ice water. The homogenate was centrifuged at $100 \mathrm{~g}$ for $10 \mathrm{~min}$ to sediment the cellular debris. The mixture containing $\left[{ }^{14} \mathrm{C}\right]$ testosterone $(0.1$ $\mu \mathrm{Ci})$, NADPH $(1 \mu \mathrm{M})$, homogenate and $0.1 \mathrm{M}$ phosphate buffer in a final volume of $1 \mathrm{ml}$ at $\mathrm{pH} 5.5$ was incubated at $37^{\circ} \mathrm{C}$ for $45 \mathrm{~min}$. Under these incubation conditions, the production of the $5 \alpha$-reduced metabolite was linear for at least $60 \mathrm{~min}$. The reaction was stopped by the addition of $0.1 \mathrm{ml}$ of $2 \mathrm{~N} \mathrm{HCl}$. The internal standards $\left[{ }^{3} \mathrm{H}\right]$ DHT $\left(500000\right.$ d.p.m.) and $\left[{ }^{3} \mathrm{H}\right]$ androstanediol (73 000 d.p.m.) were added to the incubation mixture. The mixture was applied to a Bond Elut C 18 column $(3 \mathrm{ml})$ that had been prewashed with two volumes of 
methanol followed by two volumes of distilled water. After washing the loaded column with $3 \mathrm{ml}$ distilled water, the metabolite fraction was eluted with $2 \mathrm{ml}$ methanol. The eluant was evaporated at $40{ }^{\circ} \mathrm{C}$ under vacuum, and the residues were taken up in $100 \mu \mathrm{l} 50 \%$ methanol $/ 50 \%$ chloroform. The solution was applied to a ready-made silica gel sheet on a plastic plate (Kiesel Gel ${ }^{60} \mathrm{~F}_{254}$, Merck), and the plate was developed twice using a solution of benzene/methanol (15:1) as the developer solvent. The plate was dried and used to expose x-ray film for 7 days. Separated androgens corresponding to DHT and androstenediol on the chromatogram were scraped from the plate, and the radioactivity of each was counted in a liquid scintillation counter (LSC 3500, Aloca). 5 $\alpha$-Reductase activity was calculated from the percentage of recovered radioactivity converted to DHT plus androstanediol and was recorded in terms of $\mathrm{pmol} / \mathrm{h} / \mathrm{mg}$ protein.

\section{Estrogen receptor assay}

The nuclear and cytosolic estrogen receptors (ERs) were assayed according to the method of Leake et al. (19). Approximately $700 \mathrm{mg}$ tissue was homogenized with an Ultra-Turrax homogenizer in seven volumes of ice-cold TEDG buffer (10 mM Tris-HCl, pH 7.4, 1.5 mM EDTA, $10 \%$ glycerol and $1 \mathrm{mM}$ dithiothreitol) using three $5 \mathrm{~s}$ periods, with 2 min cooling intervals between bursts. The homogenate was centrifuged at $900 \boldsymbol{g}$ for $10 \mathrm{~min}$ to prepare a crude nuclear pellet. The supernatant was added to sodium molybdate $(1 \mathrm{mM})$ and then centrifuged at $105000 \mathrm{~g}$ for $60 \mathrm{~min}$ to yield the cytosol fraction. The nuclear pellet was washed in two volumes of TEDG buffer. The crude nuclear fraction was suspended in TEDK buffer (10 mM Tris-HCl, pH 7.4, $1.5 \mathrm{mM}$ EDTA, $0.6 \mathrm{M} \mathrm{KCl}, 1 \mathrm{mM}$ dithiothreitol) and stirred gently at $4^{\circ} \mathrm{C}$ for $1 \mathrm{~h}$, and the solution was centrifuged at $105000 \mathrm{~g}$ for $60 \mathrm{~min}$. The supernatant was used for the nuclear receptor assay. Each fraction were incubated with $1-16 \mathrm{nM}$ of $\left[{ }^{3} \mathrm{H}\right]$ estradiol at $4{ }^{\circ} \mathrm{C}$ for $24 \mathrm{~h}$ in the presence or absence of $3 \mu \mathrm{M}$ DES for determination of nonspecific binding. Bound steroid was separated from free steroid using the dextran-coated charcoal (DCC) technique. All determinations were done in duplicate. The receptor concentrations were then obtained using Scatchard plots after subtraction of nonspecific bindings, and specific binding was expressed in $\mathrm{fmol} / \mathrm{mg}$ DNA for nuclear ER and in $\mathrm{fmol} / \mathrm{mg}$ protein for cytosolic ER. Prostatic DNA content was determined by the method of Burton using calf thymus DNA as a standard (20).

\section{Histopathological study and immunohistochemistry}

Prostate tissues were placed in 10\% neutral buffered formalin. Histological preparations of paraffinembedded samples were sectioned at $6 \mu \mathrm{m}$, stained with Hematoxylin and Eosin and examined by light microscopy.

Immunohistochemistry of AR was carried out according to the modified method reported previously (21). Frozen sections of prostates were incubated overnight at $4{ }^{\circ} \mathrm{C}$ with 1500 -fold-diluted anti-AR antibody (NH27) that was produced and supplied by Dr A Mizogami (Department of Urology, University of Occupational and Environmental Health, Fukuoka, Japan) (22). The anti-AR antibody produced polyclonal antibodies against human AR (hAR) by means of immunizing a rabbit with hAR fusion protein that was expressed in $E$. coli. The indirect $A B C$ method was performed with an avidin-biotin peroxidase kit (DAKO LSAB2 kit, DAKO Co., Carpinteria, CA, USA), using diaminobenzidine tetrachloride as a chromagen. The sections were stained with Methyl Green as a nuclear counterstain.

\section{Analytical methods to estimate the proportions of the epithelium and stroma}

The proportions (\%) of the histological components were calculated in Azan-Mallory-stained specimens using the modified method of Shibata et al. (9). Microscopic images of each tissue were captured on a Macintosh computer at a magnification of $\times 200$. The captured images were analyzed for the area of four components, glandular epithelium, smooth muscle, fibrous tissue and glandular lumen using a microscopic pattern-measuring system (ATTO Co., Japan). At least eight randomly chosen test areas were analyzed for each tissue specimen, to exclude the effects of heterogeneity. At first, the total area of the images was calculated. Next, the proportions of three components, glandular epithelium, fibrous tissue and glandular lumen, were calculated. Then the proportions of the area of smooth muscle were obtained by removing the other three compartments from the total area.

\section{Statistics}

Statistical significance was determined by Student's $t$ test. Differences were considered significant when $P$ was smaller than 0.05. Values are expressed as the median and 25th and 75th percentiles unless otherwise indicated.

\section{Results \\ Effects of TZA-2237 on hormone-induced canine BPH}

The change in prostate volume, expressed as a percentage of the prostate volume at 2 months after the start of testosterone and A-dione treatment, is presented in Fig. 2. Treatment with $2.5 \mathrm{mg} / \mathrm{kg}$ TZA2237 reduced prostate growth from the fourth month onward compared with the control or with $0.5 \mathrm{mg} / \mathrm{kg}$ 


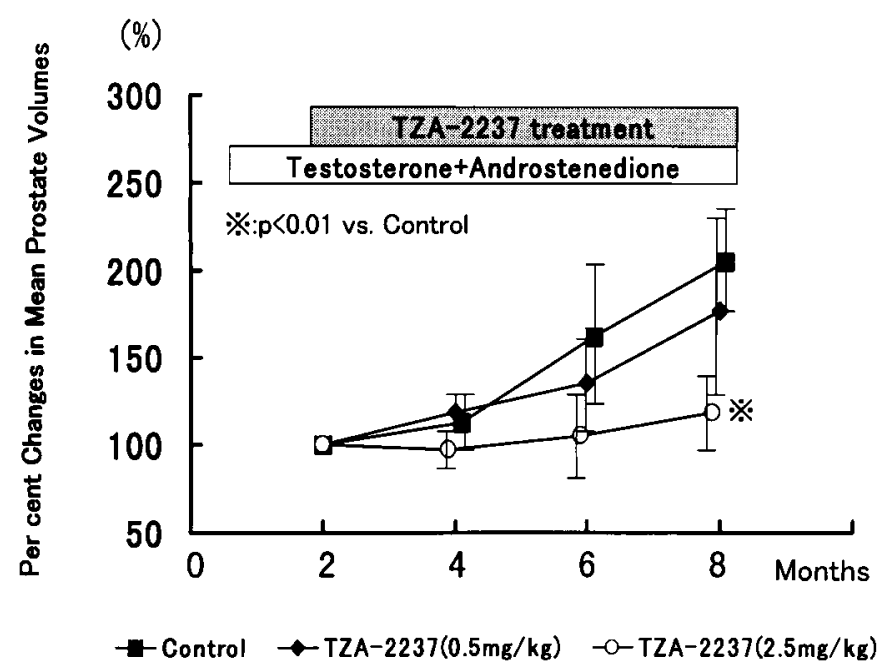

Figure 2 Sequential change of mean prostate volume estimated by transrectal ultrasonography during treatment with TZA-2237 on hormone-induced canine $\mathrm{BPH}$.
TZA-2237 treatment. There was no difference in the final body weight or final to initial body weight ratio among the three groups at necropsy. Treatment with $2.5 \mathrm{mg} / \mathrm{kg}$ TZA-2237 reduced normalized (per kg body weight) adrenal and prostatic weights compared with control or $0.5 \mathrm{mg} / \mathrm{kg}$ TZA-2237 treatment (Table 2). There was no difference in the other organ weights among the three groups.

Prostatic DHT and estradiol concentrations in each group are shown in Table 3. Treatment with $2.5 \mathrm{mg} / \mathrm{kg}$ TZA-2237 induced a significant decrease in intraprostatic estradiol concentration, but induced a significant increase in intraprostatic DHT levels compared with controls. Prostatic $5 \alpha$-reductase activity in the $2.5 \mathrm{mg} / \mathrm{kg}$ TZA-2237 group was significantly higher than that in the control group (Table 4). There were no significant differences in the cytosolic or nuclear ER contents among the 3 groups (Table 5). Scatchard plot analysis demonstrated only one binding site, and the ER measured in this study were type I.

Figure 3 shows an immunohistochemical demonstration of AR in each group. The treatment with testosterone and A-dione (control group) induced a pronounced stimulation of AR content exclusively within the epithelial compartment, and this stimulation was completely antagonized by the treatment with $2.5 \mathrm{mg} / \mathrm{kg}$ TZA-2237. The percentage of AR-positive nuclei was 74 and $22 \%$ in the control group and the $2.5 \mathrm{mg} / \mathrm{kg}$ TZA-2237 treated group respectively.

\section{Effects of TZA-2237 on spontaneous canine BPH}

The change in prostate volume, expressed as a percentage of the prostate volume at the start of treatment, is presented in Fig. 4. The prostatic weights increased significantly from 18 weeks onward in the aromatase inhibition groups (Groups V, VI and VII) compared with the controls (Group IV). TZA-2237 and Atamestane treatment increased normalized (per kg body weight) prostatic weights compared with the controls (Table 2). There were no differences in the other organ weights among the three groups.

The mean serum LH concentrations in controls, aromatase inhibition and antiandrogen-treated dogs are illustrated in Fig. 5A. In control dogs, the serum LH

Table 2 Final body weight and excised organ weight.

\begin{tabular}{lccc}
\hline Group & Body weight $(\mathrm{kg})$ & Prostate $(\mathrm{g})$ & Adrenal gland $(\mathrm{g})$ \\
\hline II & $12.3 \pm 1.0$ & $26.0 \pm 12.1$ & $1.02 \pm 0.08$ \\
II & $13.5 \pm 0.4$ & $25.9 \pm 8.8$ & $1.12 \pm 0.08$ \\
III & $13.2 \pm 0.5$ & $15.8 \pm 0.6$ & $0.88 \pm 0.08$ \\
IV & $14.8 \pm 2.1$ & $23.6 \pm 11.8$ & $1.27 \pm 0.22$ \\
V & $16.0 \pm 1.4$ & $41.1 \pm 17.3$ & $1.44 \pm 0.10$ \\
VI & $14.8 \pm 2.2$ & $37.0 \pm 11.2$ & $1.08 \pm 0.20$ \\
VII & $14.6 \pm 1.6$ & $31.8 \pm 1.7$ & $1.18 \pm 0.37$ \\
VIII & $15.5 \pm 1.0$ & $6.6 \pm 0.8$ & $0.59 \pm 0.09$ \\
IX & $15.3 \pm 4.9$ & $16.6 \pm 9.2$ & $1.38 \pm 0.03$ \\
X & $15.8 \pm 0.3$ & $15.5 \pm 2.5$ & $1.44 \pm 0.17$ \\
\hline
\end{tabular}


Table 3 The concentrations of testosterone, DHT and estradiol in the prostate.

\begin{tabular}{lccc}
\hline Group & $\begin{array}{c}\text { Testosterone } \\
\text { (ng/g tissue weight) }\end{array}$ & $\begin{array}{c}\text { DHT } \\
\text { (ng/g tissue weight) }\end{array}$ & $\begin{array}{c}\text { Estradiol } \\
\text { (pg/g tissue weight) }\end{array}$ \\
\hline I & n.d. & $14.04 \pm 3.34$ & $1332 \pm 267$ \\
II & n.d. & $13.02 \pm 1.87$ & $2332 \pm 1434$ \\
III & n.d. & $22.04 \pm 7.68^{\mathrm{b}}$ & $797 \pm 189^{\mathrm{a}}$ \\
IV & $1.22 \pm 0.90$ & $9.64 \pm 2.98$ & $117 \pm 34$ \\
V & $1.27 \pm 0.53$ & $4.77 \pm 1.76^{\mathrm{c}}$ & $62 \pm 25$ \\
VI & $0.65 \pm 0.30$ & $6.03 \pm 2.12$ & $61 \pm 14^{\mathrm{c}}$ \\
VII & $1.66 \pm 0.77$ & $13.66 \pm 3.55$ & $121 \pm 33$ \\
VIII & $0.58 \pm 0.25$ & $2.08 \pm 0.84^{\mathrm{c}}$ & $58 \pm 24^{\mathrm{c}}$ \\
IX & $0.21 \pm 0.03$ & $8.80 \pm 3.24$ & $14 \pm 3$ \\
X & $0.36 \pm 0.19$ & $4.61 \pm 1.23$ & $47 \pm 35$ \\
\hline n.d.: not determined. ${ }^{\mathrm{a}} P<0.05$ vs. Group I. ${ }^{\mathrm{b}} P<0.1$ vs. Group I, $P<0.05$ vs. Group II. ${ }^{\mathrm{c}} P<0.05$ \\
vs. Group IV.
\end{tabular}

concentration averaged $0.71 \mathrm{ng} / \mathrm{ml}$ over a 31 week treatment period and ranged from 0.48 to $1.42 \mathrm{ng} / \mathrm{ml}$. Following 13 weeks of treatment with $5 \mathrm{mg} / \mathrm{kg}$ TZA2237 , the serum LH concentration increased $(P<0.05)$ approximately 2 -fold, to $2.27 \mathrm{ng} / \mathrm{ml}$, and then further increased at 26 weeks of treatment to $4.40 \mathrm{ng} / \mathrm{ml}$. Following 13 weeks of low ( $1 \mathrm{mg} / \mathrm{kg})$-dose TZA-2237 treatment, the serum LH concentration was increased $(P<0.05)$ approximately 2 -fold, to $1.02 \mathrm{ng} / \mathrm{ml}$, and then further increased at 26 weeks of treatment to $3.74 \mathrm{ng} /$ $\mathrm{ml}$. The LH concentration of CMA-treated dogs was slightly higher than that of control dogs from 8 weeks onward. At the 31 week treatment period, the serum LH was 0.84 and $1.38 \mathrm{ng} / \mathrm{ml}$ in dogs treated with 5 and $1 \mathrm{mg} / \mathrm{kg}$ TZA-2237, respectively, and statistical analysis indicated no significant increase over controls.

The mean serum testosterone concentrations in controls, aromatase inhibitor- and antiandrogen-treated dogs are illustrated in Fig. 5B. Testosterone concentrations were similar in control and treated dogs in the pretreatment period. In control dogs, the testosterone concentration averaged $1.23 \mathrm{ng} / \mathrm{ml}$ over the 31 week treatment period, ranging from 0.73 to $2.5 \mathrm{ng} / \mathrm{ml}$. Following 8 weeks of treatment, the testosterone concentration increased $(P<0.05)$ approximately 4.5 fold, to $7.91 \mathrm{ng} / \mathrm{ml}$ in dogs treated with $5 \mathrm{mg} / \mathrm{kg}$ TZA-2237 and then further increased at 26 weeks

Table 4 The activity of $5 \alpha$-reductase and aromatase in the prostate.

\begin{tabular}{lcc}
\hline Group & $\begin{array}{c}5 \alpha \text {-reductase activity } \\
(\mathrm{pmol} / \mathrm{min} / \mathrm{mg} \text { protein })\end{array}$ & $\begin{array}{c}\text { Aromatase activity } \\
(\mathrm{fmol} / \mathrm{h} / \mathrm{mg} \text { protein })\end{array}$ \\
\hline I & $1.56 \pm 0.29$ & n.d. \\
II & $1.07 \pm 0.52$ & n.d. \\
III & $2.70 \pm 0.41^{\mathrm{a}}$ & n.d. \\
IV & $1.52 \pm 0.68$ & $0.29 \pm 0.14$ \\
V & $1.55 \pm 0.40$ & $0.39 \pm 0.16$ \\
VI & $1.92 \pm 0.61$ & $0.26 \pm 0.15$ \\
VII & $2.40 \pm 1.24$ & $0.98 \pm 1.00$ \\
VIII & $1.43 \pm 0.40$ & $0.53 \pm 0.22$ \\
\hline
\end{tabular}

n.d.: not determined. ${ }^{a} P<0.01$ vs. Group I. of treatment to $10.33 \mathrm{ng} / \mathrm{ml}$. In the group treated with $1 \mathrm{mg} / \mathrm{kg}$ TZA-2237, the testosterone concentration increased $(P<0.01)$ approximately 13 -fold, to $10.23 \mathrm{ng} / \mathrm{ml}$, at 26 weeks of treatment. Over the 31 week treatment period, the serum testosterone averaged $6.40 \mathrm{ng} / \mathrm{ml}$ and $3.74 \mathrm{ng} / \mathrm{ml}$ in dogs treated with 5 and $1 \mathrm{mg} / \mathrm{kg}$ TZA-2237, respectively, and statistical analysis indicated a significant $(P<0.05)$ increase over the control level. The mean ( \pm standard deviation) prostatic testosterone, DHT and estradiol concentrations in each group are shown in Table 3. The mean testosterone concentrations were not significantly different among the groups, but the mean DHT concentrations decreased significantly in the groups treated with $1 \mathrm{mg} / \mathrm{kg}$ TZA-2237 and CMA in comparison with the control group. Treatment with $5 \mathrm{mg} / \mathrm{kg}$ TZA-2237 induced a significant decrease in the intraprostatic estradiol concentration compared with controls. There was no significant difference in aromatase activity or $5 \alpha$-reductase activity among the five groups (Table 4).

\section{Effects of TZA-2237 combined with CMA on spontaneous canine BPH}

The prostate volume, expressed as a percentage of the prostate volume at the start of treatment was 106, 96, 88 and $101 \%$ in the combination treatment group and $77,74,70$ and $66 \%$ in the CMA-treated group at 5,10 , 15 and 20 weeks of treatment, respectively. The mean

Table 5 Estrogen receptor content in the prostate.

\begin{tabular}{lcc}
\hline & \multicolumn{2}{c}{ Estrogen receptor } \\
\cline { 2 - 3 } Group & $\begin{array}{c}\text { Nuclear fraction } \\
\text { (fmol/mg DNA) }\end{array}$ & $\begin{array}{c}\text { Cytosol fraction } \\
(\mathrm{fmol} / \mathrm{mg} \text { protein })\end{array}$ \\
\hline I & $579.1 \pm 123.2$ & $59.1 \pm 10.1$ \\
II & $756.1 \pm 230.1$ & $37.3 \pm 15.7$ \\
III & $715.2 \pm 218.1$ & $64.9 \pm 26.7$ \\
\hline
\end{tabular}


A

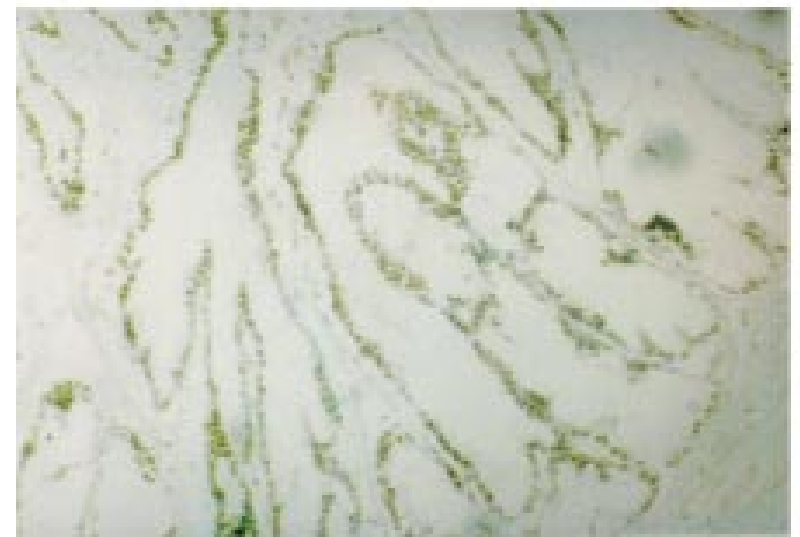

B

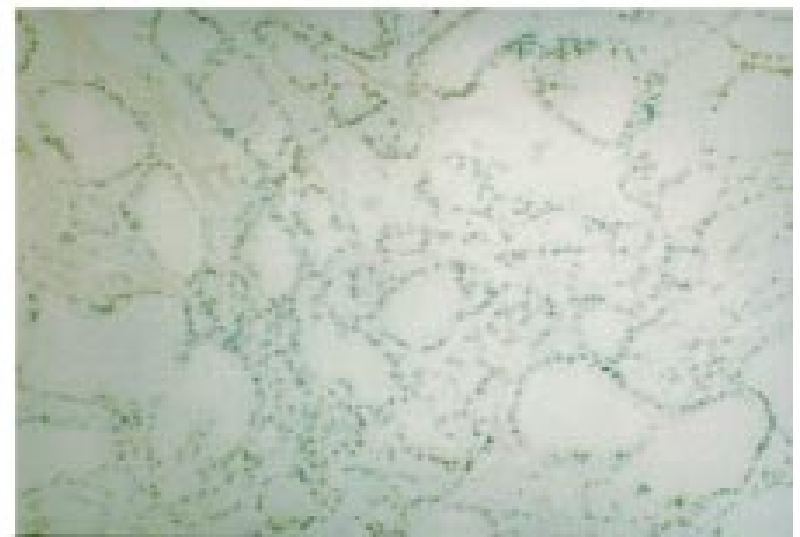

Figure 3 Immunohistochemical demonstration of androgen receptors in the prostate after 6 months of treatment with TZA-2237. (A) Control. (B) High-dose TZA-2237 group (original $\times 400$ ).

( \pm standard deviation) prostatic testosterone, DHT and estradiol concentrations in each group are shown in Table 3. Combination treatment with TZA-2237 and CMA induced a significant decrease in the intraprostatic estradiol concentration compared with all other groups. The testosterone and DHT concentrations in the combined treatment group (Group IX) were not increased relative to those in the control group.

The volume densities of various histological components evaluated by quantitative morphometric analysis in each group are shown in Fig. 6. The proportions of the glandular lumen, glandular epithelium, connective tissue and smooth muscle were 19.5, 48.0, 5.0 and $27.5 \%$, respectively, in the controls, $14.0,44.0,6.0$ and $36.0 \%$ in the group treated with $0.03 \mathrm{mg}$ CMA and $12.4,45.8,26.6$ and $15.6 \%$ in the combined treatment group. The proportion of smooth muscle compartment in the combined treatment group was significantly decreased compared with the proportion in the group treated with $0.03 \mathrm{mg}$ CMA and the control group.

\section{Discussion}

Androgens are widely acknowledged to be central to the pathogenesis of BPH. In this respect, the treatment with $5 \alpha$-reductase inhibitor and androgen ablation therapy have achieved some success in decreasing prostate size, and improving symptoms and urinary flow rates (23-25). However, the development of BPH is considered to be attributed to a benign proliferative process of the stromal and epithelial elements of the prostate. Therefore, it might be expected that the poor response to hormonal treatment was caused by the accumulation of

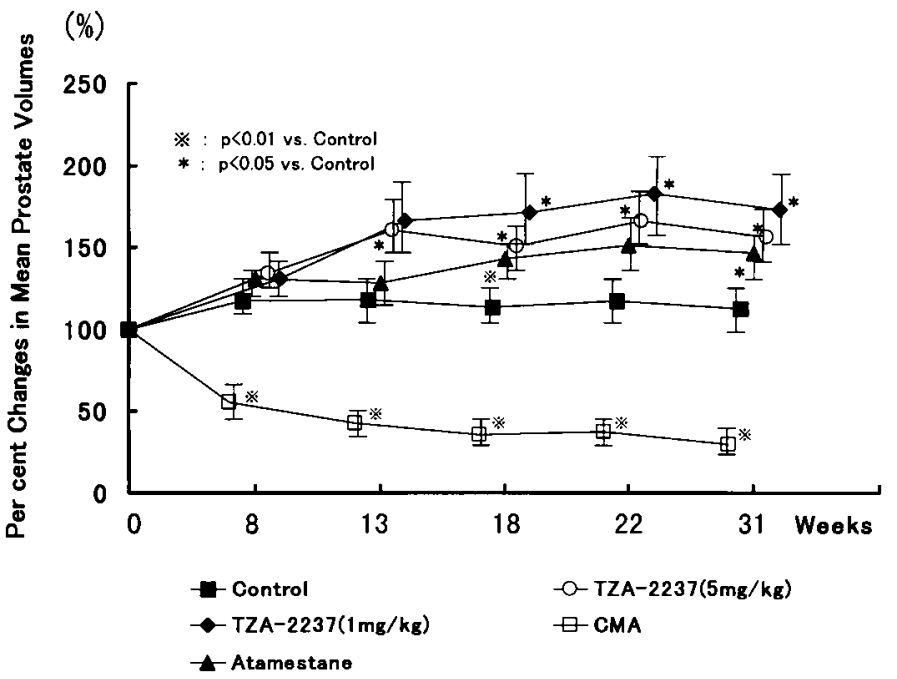

www.eje.org
Figure 4 Sequential change of mean prostate volume in cases of spontaneous canine BPH estimated by transrectal ultrasonography during treatment with aromatase inhibitor or antiandrogen 
A

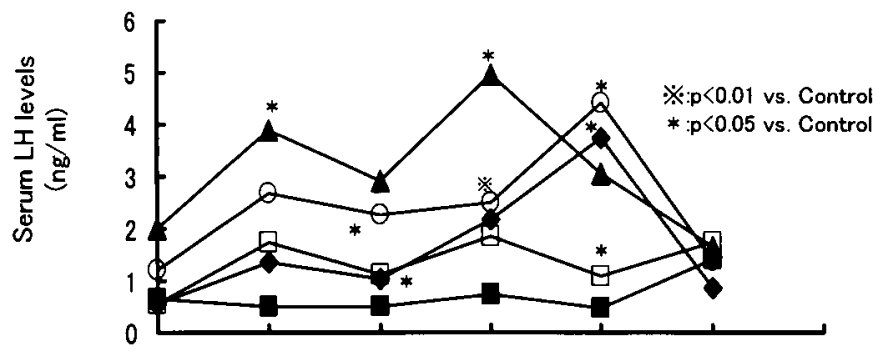

B

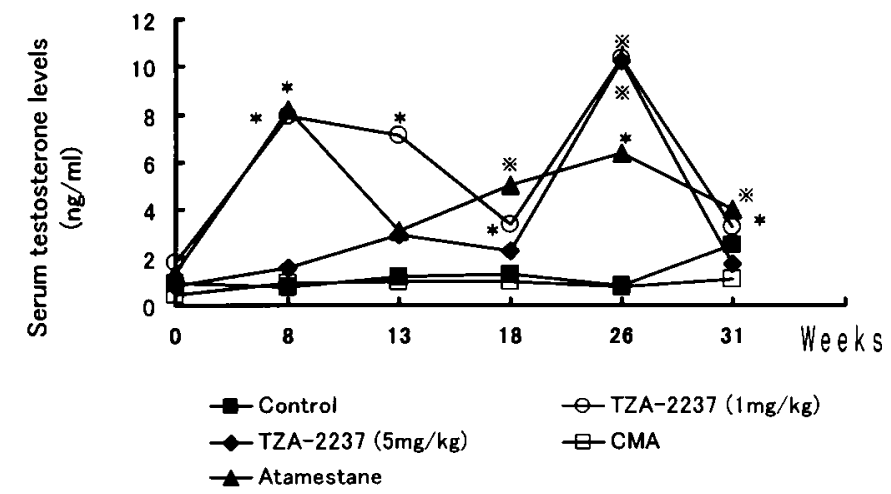

Figure 5 Mean serum $\mathrm{LH}(\mathrm{A})$ and testosterone (B) concentrations $(\mathrm{ng} / \mathrm{ml})$ in controls, aromatase inhibitor-, and antiandrogen-treated dogs. connective tissue in the hyperplastic human prostate. Several authors reported that an absolute increase in the stromal elements of the prostate, rather than glandular hyperplasia, was the most important morphological finding in human BPH (26-29). The correlation of the extent of clinical symptoms with $\mathrm{BPH}$ size, pathologic type and location of the lesions, as well as smooth muscle and neurologic control of prostate tone, remain to be elucidated, and it is well known that the severity of clinical symptoms of $\mathrm{BPH}$ is not related to the size of the hyperplastic prostate (30). The bladder outlet obstruction in symptomatic $\mathrm{BPH}$ appears to be affected not only by mechanical obstruction due to the enlarging adenoma but also to the tone of the prostate smooth muscle (31). Several studies have demonstrated that one of the endocrinological factors in the pathogenesis of $\mathrm{BPH}$ is estrogen stimulation of stromal

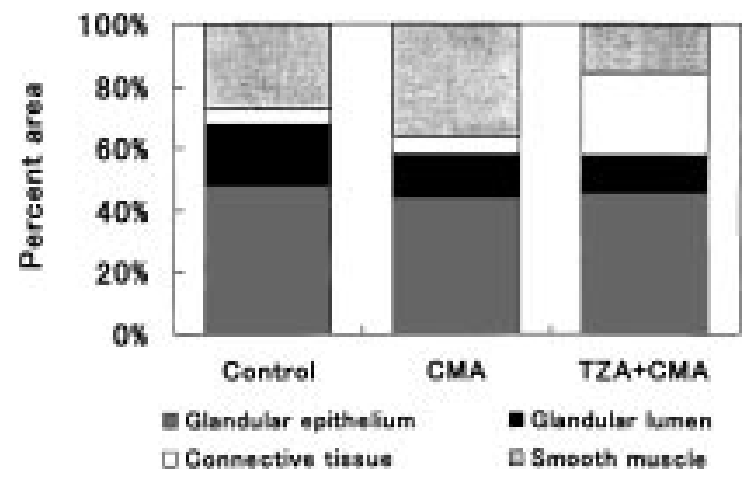

Figure 6 The proportions of the glandular lumen, glandular epithelium, connective tissue, and smooth muscle in controls, CMA, TZA-2237and CMA groups. growth. Animal experiments have emphasized the potential role of estrogens in the pathogenesis of $\mathrm{BPH}$ (32-35). Habenicht et al. first demonstrated the effect of aromatase inhibitor, 4-hydroxy-4-androstene-3,17dione, on the experimentally induced BPH in the dog (36). They suggested that estrogen-related effects could be clearly antagonized by simultaneous treatment with the aromatase inhibitor. Recently, Krieg et al. demonstrated an age-dependent decrease in the DHT level in the epithelium and a concomitant increase of estrone and estradiol levels in stroma. This, in turn, could be of pathogenic importance for BPH development if in fact a balanced estrogen/androgen synergism is necessary for integrity and normal growth of the prostate (4). Recently, the highest expression of ER- $\beta$ mRNA was found in the prostate among the various tissues tested, and this suggests that the prostate may be an important target in which to explore ER- $\beta$ protein expression once antibodies or ligands of sufficient specificity and quality become available $(37,38)$. Nakano et al. demonstrated by an immunohistochemical study that $\mathrm{ER}-\beta$ protein is expressed specifically in the human prostatic epithelium and ER- $\alpha$ in the stroma (11). Therefore, decreased estrogen stimulation of the prostatic stroma in patients treated with an aromatase inhibitor should be a promising novel treatment of $\mathrm{BPH}$.

The findings of the present study clearly indicated that $2.5 \mathrm{mg} / \mathrm{kg}$ TZA-2237 significantly suppressed hormone-induced prostatic growth. We investigated the inhibitory mechanism of this compound using biochemical and immunohistological analyses. In the prostate, a much lower estradiol concentration, but much a higher DHT level and $5 \alpha$-reductase activity was demonstrated in the group treated with $2.5 \mathrm{mg} / \mathrm{kg}$ 
TZA-2237 than in the control group. The reason for the higher DHT level and $5 \alpha$-reductase activity is unclear, but the consumption of the substrate was lowered by aromatase inhibitor administration, and the $5 \alpha$ reductase activity was secondarily activated, and then the concentration of DHT in the prostate increased. Moreover, $2.5 \mathrm{mg} / \mathrm{kg}$ TZA-2237 caused a significant decrease in androgen receptor content in comparison with that of the other groups as shown in the immunohistochemical study, although the estrogen receptor content showed no significant difference among the three groups in the biochemical study. It is expected that this inhibitory effect in the group treated with $2.5 \mathrm{mg} / \mathrm{kg}$ TZA-2237 was exerted via a significant decrease in the intraprostatic estradiol level and epithelial androgen receptor concentration. Estrogens in combination with androgens increase the prostatic nuclear androgen receptor content of the canine prostate (33). Moreover, it has been demonstrated that estrogen, mediated by the SHBG-receptor complex, participates with androgen in setting the pace of prostate growth and function (10). It has also been demonstrated that estradiol and $5 \alpha$-androstan- $3 \alpha, 17$ $\beta$-diol causes a marked dose-dependent increase in stromal cytosolic cAMP in the presence of receptorbound SHBG $(11,34)$. In addition, it would appear that the estrogen not only directs stromal proliferation and secretion, but also, through IGF-I synthesis mediated by cAMP, conditions the response of the epithelium to androgen (10). Estrogen also has indirect effects on the prostate, including estrogen's ability to cause a marked increase in the release of prolactin from the anterior pituitary. Prolactin has been shown to stimulate the citric acid production in the rat lateral prostate $(39,40)$. Lloyd et al. demonstrated that prolactin alters androgen uptake and metabolism in the prostate (41). Recent studies have also shown that the permeability of the prostatic cell membrane to androgen in patients with $\mathrm{BPH}$ may be altered in response to prolactin (42). From these perspectives, it is possible that a significant decrease of estradiol in the prostate suppresses a protein kinase pathway in the stroma, and this biochemical change inhibits stromal proliferation directly and epithelial proliferation indirectly through IGF-I and androgen receptor suppression. It is also expected that a decrease of prolactin suppresses prostatic growth. Moreover, Yeh et al. (11) demonstrated that ARA70, a steroid receptor coactivator 1 , can induce AR transcriptional activity $>30$-fold in the presence of $10 \mathrm{nM} 17 \beta$ estradiol. $\mathrm{E}_{2}$ represents another important natural ligand for AR that may play an essential role in the AR function and the development of the male reproductive system. Therefore, this new pathway for $\mathrm{E}_{2}$ may play an important role in the prostate.

Some investigators have reported effects of other aromatase inhibitors, 1-methyl-1,4-androstadiene3,17-dione (Atamestane) (43-45), and 7-mercapto-Dhomo-17-oxa-androsta-1,4-dien-3-one

(TZA-2209)
(46), in the treatment of BPH. Haebenicht \& Etreby demonstrated the inhibitory effects of Atamestane on androstenedione-induced hyperplastic effects in the prostates of castrated dogs (43). In addition, they also demonstrated that treatment of intact cynomolgus monkeys with androstenedione resulted in estrogenrelated changes, particularly in the stroma of the prostate, and these effects were antagonized by simultaneous treatment with Atamestane (44). However, the possibility that the suppression of estrogen resulted in a counter-regulatory increase in androgen, and thereby evoked epithelial growth, must be considered. Using morphometric analysis, Suzuki et al. demonstrated that the administration of TZA-2209 led to a significant decrease in stroma and a significant increase in the canine prostate (46). Juniewicz et al. reported a change in the endocrine environment of aromatase inhibitor, 4-(5,6,7,8-tetrahydroimidazo [1,5a] pyridin-5-yl) benzonitride hydrochroride, for intact male dogs (47). They demonstrated that inhibition of estrogen biosynthesis results in increased serum $\mathrm{LH}$ and testosterone concentrations as well as increased capacity of the testis to secrete androgens in response to LH. The findings of the present study clearly indicated that the treatment of spontaneous canine $\mathrm{BPH}$ with aromatase inhibitor increased serum LH and testosterone concentrations. Thus, it is not surprising that the findings of the present study clearly indicate that an aromatase inhibitor significantly increased prostatic growth in dogs with spontaneous BPH. Moreover, a recent placebo-controlled double-blind study demonstrated that Atamestane is not an effective treatment for symptomatic BPH (14). The possibility that a counterregulatory increase in androgens may counterbalance any positive effect of the decrease in estrogens to preserve intraprostatic homeostasis was discussed relative to that finding. However, since this failure resulted in a counter-regulatory increase in androgens, one cannot exclude the therapeutic possibility of estrogen deprivation for $\mathrm{BPH}$. The change in the endocrine environment of serum $\mathrm{LH}$ and testosterone resulting from the administration of aromatase inhibitor was similar between dogs and humans in the present study.

Recently, we assessed the effect of dual inhibition of $5 \alpha$-reductase and aromatase on spontaneously developed canine prostatic hypertrophy (48). Administration of a $5 \alpha$-reductase inhibitor, finasteride, and an aromatase inhibitor, arimidex, resulted in a significant increase in prostate volume, accompanied by a 3- to 10-fold increase in serum testosterone levels and a significant increase in testicular volume. In connection with the synergistic effects of Atamestane and antiandrogen cyproterone acetate (CPA), it would appear that CPA in combination with Atamestane induced a selective and complete inhibition of the androgenic effects at the level of the prostate, while CPA did not negatively influence the function of the testis, the 
epididymidis or the pituitary (45). These experimental findings demonstrated that estrogen deprivation with antiandrogen might represent a useful treatment for human BPH. We investigated the synergistic effect of TZA-2237 and CMA on spontaneous canine BPH. Combination treatment with CMA and TZA-2237 induced a significant decrease in the intraprostatic estradiol concentration, and a significant decrease in the smooth muscle component. The decrease in smooth muscle which is related to the neurologic control of prostate tone may improve the clinical symptoms of $\mathrm{BPH}$. However, these combination treatments did not decrease the prostate volume and the relative volumes of glandular epithelium and lumen, and the intraprostatic DHT concentration of the combination treatment group increased to the level similar to the control group. There were clear endocrinological and morphological changes in the prostates of dogs treated with aromatase inhibitor and antiandrogen. It is still necessary to determine the most effective dose of aromatase inhibitor and antiandrogen, and to investigate various factors such as urethral compliance, $\alpha_{1}$ receptor content, residual urine volume, ER- $\beta$ expression and apoptosis. It is hoped that these studies will give us definitive information in the near future. In addition, it is important to investigate the role of the SHBG-steroid-responsive second messenger system, ER $\beta$ and ARA70, in the prostate, and to understand how estrogen modulates the autocrine relationship within the stroma and the paracrine relationship between stroma and epithelium.

\section{References}

1 Berry SJ, Coffey DS, Walsh PC \& Ewing LL. The development of human benign prostatic hyperplasia with age. Journal of Urology $1984132474-479$.

2 Pinke KM \& Doerr P. Age related changes and interrelationships between plasma testosterone, oestradiol and testosterone-binding globulin in normal adult males. Acta Endcrinologica 197374 792-800.

3 Krieg M, Nass R \& Tunn S. Effect of aging on endogenous level of $5 \alpha$-dihydro-testosterone, testosterone, estradiol and estrone in epithelium and stroma of normal and hyperplastic human prostate. Journal of Clinical Endocrinology and Metabolism 1993 77 375-381.

4 Davidson JM, Chen JJ, Crapo L, Gray GD, Greenleaf WJ \& Catania JA. Hormonal changes and sexual function in aging men. Journal of Clinical Endocrinology and Metabolism 198357 71-77.

5 Tenover JS, Matsumoto AM, Plymate SR \& Bremner WJ. The effects of aging in normal men on bioavailable testosterone and luteinizing hormone secretion: response to clomiphene citrate. Journal of Clinical Endocrinology and Metabolism 198765 1118-1126.

6 Ito K. The evidence of estrogen production in the prostate. Nippon Naibunpi Gakkai Zasshi 199672 1021-1033.

7 Seppelt U. Correlation among prostate stroma, plasma estrogen levels, and urinary estrogen excretion in patients with benign prostatic hypertrophy. Journal of Clinical Endocrinology and Metabolism 197847 1230-1235.

8 Suzuki K, Ito K, Ichinose Y, Kurokawa K, Suzuki T, Imai K et al. Endocrine environment of benign prostate hyperplasia Prostate size and volume are correlated with serum estrogen concentration. Scandinavian Journal of Urology and Nephrology $19952965-68$.

9 Shibata Y, Ito K, Suzuki K, Nakano K, Fukabori Y, Suzuki R et al. Changes in the endocrine environment of the human prostate transition zone with aging - Simultaneous quantitative analysis of prostatic sex steroids and comparison with human prostatic histological composition. Prostate 200042 45-55.

10 Fukabori Y, Nakano K, Shibata Y, Kurokawa K, Yuasa H, Yamanaka H. Androgen-regulated estrogen receptor $\beta$ expression in human prostate. Journal of Urology 1999161 (suppl) 124.

11 Yeh S, Miyamoto H, Shima H \& Chang C. From estrogen to androgen receptor: A new pathway for sex hormone in prostate. PNAS 199895 5527-5532.

12 Farnsworth WE. Roles of estrogen and SHBG in prostate physiology. Prostate 199628 17-23.

13 Nakhla AM, Khan MS, Romas NP \& Rosner W. Estradiol causes rapid accumulation of c-AMP in human prostate. PNAS 199477 $5402-5405$

14 Gingell JC, Knonagel H, Kurth KH \& Tunn UW. The Schering 90,062 Study Group. Placebo controlled double-blind study to test the efficacy of the aromatase inhibitor atamestane in patients with benign prostaic hyperplasia not requiring operation. Journal of Urology 1995154 399-401.

15 McPhail MK. The assay of progestine. Journal of Physiology 1934 83 145-156.

16 Berry SJ, Sterner R, Cofey DS \& Ewing LL. Methods for monitoring canine prostate size: internal and external caliper measurements. Prostate 19856 303-314.

17 Nett TM, Akbar AM, Phemister RO, Holst PA, Reichert LE Jr \& Niswender GD. Level of LH, estradiol and progesterone in serum during the estrous cycle and pregnancy in the beagle bitch. Proceedings of the Society for Experimental Biology and Medicine $1975148134-139$.

18 Lowry OH, Losebrogh NJ \& Farr AF. Protein measurement with folin reagent. Journal of Biological Chemistry 1951193 265-275.

19 Leake RE \& Habib F. Steroid hormone receptors: assay and characterization. In Steroid Hormones a Practical Approach, pp 67-98. Eds B Green \& RE Leake. Oxford: IRL Press 1987.

20 Burton K. A study of the conditions and mechanism of the diphenylamine reaction for the colorometric estimation deoxyribonucleic acid. Journal of Biochemistry 195662 315- 323.

21 Suzuki K, Ito K, Kurokawa K, Suzuki T, Shimizu N, Fukabori Y et al. Expression and degradation of rat androgen receptor following castration, testosterone replacement and antiandrogens administration: analysis by Western blot and immunohistochemistry. Tohoku Journal of Experimental Medicine 1997 183 159-172.

22 Mizogami A, Masai M, Shimazaki J \& Sugai A. Production of polyclonal antibody against human androgen receptor and immunohistochemical study of human androgen receptor in prostatic tissues. Japanese Journal of Urology 199283 1801-1807.

23 Gormley GJ, Stoner E, Bruskewitz RC, Imperanto-McGinley J, Walsh PC, McConnell JD et al. The effect of finasteride in men with benign prostatic hyperplasia. New England Journal of Medicine 1992327 185-1191.

24 Peters CA \& Walsh PC. The effects of nafarelin acetate, a luteinizing hormone releasing hormone agonist, on benign prostatic hyperplasia. New England Journal of Medicine 1987 317 599-604.

25 Gabrilove JL, Levine AC, Kirgchenbaum A \& Droller M. Effect of a GMRH analogue (Leuprolide) on benign prostatic hypertrophy. $1987641331-1333$.

26 Shapiro E, Hartanto V \& Lepor H. Quantifing the smooth muscle content of the prostate using double-immunoenzymatic staining and color assisted image analysis. Journal of Urology 1992147 1167-1170.

27 Bartsch G, Muller HR, Oberholzer M \& Rohr HP. Light microscopic stereological analysis of the normal human prostate and benign prostatic hyperplasia. Journal of Urology 1979122 487-491.

28 Siegel YI, Zaidel L, Hammel I, Korczak D \& Linder A. Morphometric evaluation of benign prostate hyperplasia. European Urology $1990871-73$. 
29 Costa P, Robert M, Sarrazin B, Mottet N \& Navratil H. Quantitative topographic distribution of epithelial and mesenchymal components in benign prostatic hyperplasia. European Urology 199324 120-123.

30 Appell RA, England HR, Hussel AR \& McGuire EJ. The effect of epidural anesthesia on the urethral closure pressure profile in patients with prostatic enlargement. Journal of Urology 1980124 410-441.

31 Caine M. The present role of alpha-adrenergic blockers in the treatment of benign prostatic hypertrophy. Journal of Urology $19861361-4$

32 Walsh PC \& Wilson JD. The induction of prostatic hypertrophy in the dog with androstanediol. Journal of Clinical Investigation 1976 57 1093-1097.

33 Trachtenberg J, Hicks LL \& Walsh PC. Androgen and estrogen receptor content in spontaneous and experimentally induced canine prostatic hyperplasia. Journal of Clinial Investigation 1980 65 1051-1059.

34 Nakhla AM, Ding VDH, Khan MS, Romas NA, Rhodes L, Smith RG et al. $5 \alpha$-androstan- $3 \alpha, 17 \beta$-diol is a hormone: Stimulation of cAMP accumulation in human and dog prostate. Journal of Clinical Endcrinology Metabolism $1995 \mathbf{8 0}$ 2259-2261.

35 DeKlerk DP, Coffey DS, Ewing LL, McDermott IR, Reiner WG, Robinson $\mathrm{CH}$ et al. A comparison of spontaneous and experimentally induced canine prostatic hyperplasia. Journal of Clinical Investigation $197964842-849$.

36 Habenicht UF, Schwarz K, Schweikert HU, Neumann F \& Etreby FE. Development of a model for the induction of estrogen-related prostatic hyperplasia in the dog and its response to the aromatase inhibitor 4-hydroxy-4-androstene-3,17-dione: preliminary results. The Prostate 19868 181-194.

37 Couse JF, Lindzey J. Grandien K, Gustafsson JA \& Korach KS. Tissue distribution and quantitative analysis of estrogen receptor $\alpha(\mathrm{ER} \alpha)$ and estrogen receptor- $\beta(\mathrm{ER} \beta)$ messenger ribonucleic acid in the wild-type and ER $\alpha$-knockout mouse. Endocrinology 1997 138 4613-4621.

38 Kuiper GGJM, Carlsson B, Grandien K, Enmark E, Haggbland J, Nilsson $\mathrm{S}$ et al. Comparison of ligand binding specificity and transcript tissue distof estrogen receptors $\alpha$ and $\beta$. Endocrinology $1997138863-870$

39 Grayhack JT. Effect of testosterone-estradiol administration on citric acid and fructose content of the rat prostate. Endocrinology 196577 1068-1074.
40 Grayhack JT \& Lebowitz A. Effect of prolactin on citric acid of lateral lobe of prostate of Sprague-Dawley rats. Investigative Urology $1967587-94$.

41 Lloyd JW, Thomas JA \& Nawhinny MG. A difference in the in vitro accumulation and metabolism of testosterone-1,2-3H by the rat prostate gland following incubation with ovine or bovine prolactin. Steroids 197322 473-483.

42 Farnsworth WE. Prolactin effect on the permeability of benign hyperplastic prostate to testosterone. The Prostate 1988 $12222-229$.

43 Habenicht UF \& Etreby MFE. Rationale for using aromatase inhibitors to manage benign prostatic hyperplasia. Experimental studies. Journal of Andrology 199112 395-402.

44 Habenicht UF, Schwarz K, Neuman F \& Etreby MFE. Induction of estrogen-related hyperplastic changes in the prostate of the cynomolgus monkey (Macaca fascicularis) by androstenedione and its antagonization by the aromatase inhibitor 1-methylandrosta-1,4-diene-3,17-dione. The Prostate 198711 313326.

45 Habenicht UF \& Etreby MFE. Selective inhibition of androstenedioneinduced prostate growth in intact beagle dogs by a combined treatment with the anti-androgen cyproterone acetate and the aromatase inhibitor 1-methyl-androsta-1,4-diene-3,17-dione (1methyl-ADD). The Prostate 198914 309-322.

46 Suzuki K, Ito K, Tamura Y, Suzuki T, Honma S \& Yamanaka H. Effect of aromatase inhibitor,TZA-2209, in the prostate of androstenedione-treated castrated dogs: changes in prostate volume and histopathological findings. The Prostate 199628 328-337.

47 Juniewicz PE, Oesterling JE, Walters JR, Steele RE, Niswender GD, Coffey DS et al. Aromatase inhibition in the dog. I Effect on serum LH, serum testosterone concentrations, testicular secretions and spermatogenesis. Journal of Urology $1988139827-$ 831 .

48 Suzuki K, Okazaki H, Ono Y, Kurokawa K, Suzuki T, Omura E et al. Effect of dual inhibition of 5-alpha-reductase and aromatase on spontaneously developed canine prostatic hypertrophy. Prostate $19983770-76$

Received 27 October 1999

Accepted 2 May 2000 